\title{
Response of some wheat cultivars to plot orientation and foliar boron levels
}

\author{
Lana D. M. Marofi \\ Field Crops Department \\ College of Agricultural Engineering Sciences \\ Salahaddin University \\ Erbil, Iraq \\ lana.mohammed@su.edu.krd
}

\author{
Sami Mohammad Amin \\ Field Crops Department \\ College of Agricultural Engineering Sciences \\ Salahaddin University \\ Erbil, Iraq \\ sami.maaroof@su.edu.krd
}

Volume 4 - Issue 2

December 2019

DOI:

10.24017/science.2019.2.1

Received:

14 July 2019

Accepted:

19 August 2019

\begin{abstract}
This investigation was conducted to understand the response of three newly introduced bread wheat cultivars to Erbil area (V1: FLORKWA, V2: BAJ and V3: FRANKOLIN) to three boron levels sprayed at elongation stage 0, 1 and 1.5 ppm concentration and oriented (South-North and East-West) row directions to study the vegetative and reproductive growth characters of wheat. The results showed that Leaf area, LAI, weight of leaf, light extinction coefficient, flag leaf length, fertility, number of spike and harvest index significantly increased in EW (East-West) compared to SN (South-North) row direction. While, the spike weight, spike length, number of kernels, grain yield and biological yield significantly increased in $S N$ compare to $E W$ row direction. There were not significant differences observed among different level of boron alone and different cultivars in all studied traits except plant height and 1000 kernels weight of V2 increased compared to other cultivars. Interactions of $E W$ direction with both cultivars and levels of boron factors were improved the vegetable characteristics compared to NS direction. Grain yield of interaction between $1.5 \mathrm{ppm} \times \mathrm{SN}$, all cultivars $\times S N$ and $1.5 \mathrm{ppm}$ boron $\times V 1 \times S N$ row direction were significantly $(P<0.05)$ increased compared to other interactions. While the harvest index increased in interaction between 0 and $1.5 \mathrm{ppm} \times \mathrm{EW}, \mathrm{V} 2 \times \mathrm{EW}$ and $1.5 \mathrm{ppm} \times \mathrm{V1} \times$ $E W$ compared to other interactions.
\end{abstract}

Keywords: Wheat cultivar, Row direction, Boron, 


\section{INTRODUCTION}

One of the most serious crops in the world are wheat crop (Triticum aestivum L.) that is essential grain crops for the human and animal consumption. The ultimate yield of the wheat crop is controlled by a number of external factors and genetics [1]. Wheat is one of the cheapest exporters of food that supplies $72 \%$ calories and protein with other important ingredients in the normal life of humans.

In any case of the convenient role of the row direction in influencing the yield of crops, they also have a direct role in preserving soil water from evaporation. The results also by [2], showed that the influence of row directions, and the spacing of grade in the agricultural process is very important in increasing crop production and controlling weed-related with wheat crops. The impact of row direction on crop yields is different, depending on the farming system, is likely to vary from crop cultivars [3]. Also, several published papers on this point confirm that set the row direction of crops with row spacing is very serious to increase the yield of crops [4], [5], [6], [7]. The rows direction that has impact on the adequacy of photosynthesis and the temperature of the canopy influenced by the challenge of solar radiance and the canopy of crops [8].

Deficiency of boron in cereal is more common than the reduction of any other microelement in the world [9]. Adequate boron is crucial for high production and high quality of plants [10]. Deficiency of boron reasons many physiological, biochemical, and anatomical modifications in plants [11]. Boron has abundant physiological assignment in crops such as synthesis of cell wall, sugar transport, pollen tube growth, pollen germination, reproduction, carbohydrate metabolism, lignification, RNA metabolism, respiration, indole acetic acid metabolism (IAA), phenol metabolism, membrane integrity, ascorbate metabolism and oxygen activation [11], [12].

The objective of this research was to find out the reaction of some wheat cultivars to plot orientation and different level of boron sprayed on the plants for growth and wheat production.

\subsection{Experimental design}

\section{MATERIALS AND METHODS}

This experiment was carried out in Grdarasha experimental station, College of Agricultural Engineering Sciences, Salahaddin University, Kurdistan Region, Erbil, during the winter season 2018-2019. Three newly introduced bread wheat cultivars (V1: FLORKWA, V2: BAJ and V3: FRANKOLIN) were used in this research. The wheat (V1, V2 and V3) certified from Erbil Agricultural Experimental Station were distributed in ordinance on plots of area $1 \mathrm{~m} \times 2 \mathrm{~m}$ (area of each plot about $2 \mathrm{~m}-2$ ), line spacing $17 \mathrm{~cm}$, each cultivar sprayed at elongation stage with either 0 , 1 and 1.5 ppm concentration of boron. Each of the three replicates contained 9 experimental units ( 3 cultivars by 3 boron level) so that each oriented (South-North and East-West) band occupied 27 square meters and both orientations 54 net square meters in addition to boundaries and path ways. Boundaries (Buffers) were about one-meter strip and the walkways about 0.5 meters, to form a total area of $300 \mathrm{~m}^{2}$. Physical and chemical properties were analyzed at a depth $(0-30 \mathrm{~cm})$ of experiment soil (Table 1). 
Table 1: Physical and chemical properties of experiment soil at a depth $(0-30 \mathrm{~cm})$.

\begin{tabular}{l|c|c}
\hline \multicolumn{2}{c}{ Soil properties } & $\mathbf{0 - 3 0} \mathbf{~ c m}$ \\
\hline \multirow{4}{*}{ Particle distribution } & Sand \% & 36.23 \\
\cline { 2 - 3 } & Silt \% & 31.73 \\
\cline { 2 - 3 } & Clay \% & 30.83 \\
\cline { 2 - 3 } & Soil texture & Clay Loam \\
\hline \multirow{4}{*}{ Organic matter } & OM \% & 0.8 \\
\cline { 2 - 3 } & N Total (\%) & 0.06 \\
\cline { 2 - 3 } & P Available (ppm) & 4.64 \\
\cline { 2 - 3 } & K Available (ppm) & 177.33 \\
\cline { 2 - 3 } & EC ds.m -1 & 0.23 \\
\cline { 2 - 3 } & pH & 7.7 \\
\hline
\end{tabular}

\subsection{Characteristics studied}

\subsubsection{Vegetative growth characters}

Plant height $(\mathrm{cm})$ was recorded at maturity, ten representative plants were collected at in random from each treatment, the height of plants was estimated excluding awns from the flat area of the ground to the growing point of the spikes and then the average plant height was obtained. A number of tillers calculated from $50 \mathrm{~cm}$ length randomly from the central rows of plots at the harvesting stage [13]. Flag leaf length (the distance between the collar and the tip of fully expanded flag leaf) were measured at the flowering stage and calculated as the mean of ten leaves at the main stem for each plot. Light intensity was measured as light conflicts coefficient with Photometer Luxomet 300 Model (M/S Research Instrumentation, New Delhi, India) at lower and upper of crop canopy. Leaf area was measured of the plant growth and calculated by image $\mathrm{J}$ software.

\subsubsection{Reproductive growth characters}

At the end of the experiment, reproductive growth characters were calculated from the random 50 $\mathrm{cm}$ length per plot from central rows; includes number of spikes plant ${ }^{-1}$, spike length $(\mathrm{cm})$ and weight (g), number of kernels spike ${ }^{-1}, 1000$-kernel weight (g), Grain yield (g plant ${ }^{-1}$ ), Biological yield ( g plant $^{-1}$ ) and Harvest index (HI).

\subsection{Statistical Analysis}

Results were obtained in the experiments were statistically analyzed using General Linear Model (GLM) according to the analysis of variance (ANOVA) using SPSS program (Statistical Package for Social Science) (SPSS 22, 2005) for Factorial - RCB design. Descriptive statistics were used for the analysis of the data result as follow, means and standard error. Duncan test was utilized to calculate significant differences at $5 \%$ levels among the various parameters [14].

\section{RESULTS AND DISCUSSIONS}

\subsection{Vegetable growth characters}

Table 2A shows that not significant differences $(\mathrm{P}>0.05)$ were observed among treatments for the number of tillers plant ${ }^{-1}$ in row directions, cultivars, different level of boron and boron levels $\times$ row directions at 122 days after sowing. While, the number of tillers plant ${ }^{-1}$ were increased in the interactions between $1.5 \mathrm{ppm}$ of boron $\times \mathrm{V} 1$ and V2 $\times \mathrm{SN}$ row direction compared with other interactions. Also, the interactions among three factors $(1.5 \mathrm{ppm}$ boron $\times \mathrm{V} 1 \times \mathrm{SN}, 1 \mathrm{ppm}$ boron $\times$ $\mathrm{V} 2 \times \mathrm{SN}$ and $0 \mathrm{ppm}$ boron $\times \mathrm{V} 1 \times \mathrm{EW}$ ) were higher compared with the other interactions. The number of spikes was increased due to the higher fertile tillers at the end of the crop cycle. The results by [14] found that boron administration increased 15\% the number of tillers per plant of 
wheat. Also, the research by [16] found that the effect of application of different level of boron under natural drought conditions of Hawler area during growing season of 2002-2003, have been studied on leaf area, LAI and leaf area duration, boron affect significantly the leaf area at both seasons. No significant effect observed in number of tiller and plant height using different level of boron.

The data presented in table 2A showed that leaf area, leaf area index and weight of leaf at 122 days after sowing were significantly $(\mathrm{P}<0.05)$ increased in EW compared to SN row direction. While, there were no significant differences among different level of boron, three cultivars and interaction between boron $\times$ cultivars in all parameters. This study not consistent with some other researchers that found plant height and flag leaf insertion height significantly increased with administration of boron [17], [18]. The results indicated that the interaction between various level of boron and row directions also had significant $(\mathrm{P}<0.05)$ differences among treatments, the best result of leaf area, LAI and weight of leaf were recorded for $1 \mathrm{ppm}$ of boron $\times \mathrm{EW}$ compared with other interactions. Also, the results showed that the interaction between cultivars and row directions had significant $(\mathrm{P}<0.05)$ differences among treatments, the best result of leaf area and LAI was recorded for $\mathrm{V} 2 \times \mathrm{EW}$ and the best result of weight of leaf were recorded for $\mathrm{V} 1 \times \mathrm{EW}$ and V2 $\times$ EW compared with other interactions.

While, the interaction among three factors; cultivars, different level of boron and row directions showed the significant $(\mathrm{P}<0.05)$ differences among treatments, the best result of leaf area and LAI were recorded for $\mathrm{V} 2 \times 1.5 \mathrm{ppm}$ of boron $\times \mathrm{EW}, \mathrm{V} 3 \times 1 \mathrm{ppm}$ of boron $\times \mathrm{EW}$ and $\mathrm{V} 2 \times 0 \mathrm{ppm}$ of boron $\times \mathrm{EW}$ compared with other interactions. The lowest leaf area, LAI and weight of leaf was recorded for $\mathrm{V} 1 \times 1 \mathrm{ppm}$ of boron $\times \mathrm{SN}$ compared with other interactions. While, the best result of leaf Weight was recorded for $\mathrm{V} 1 \times 1 \mathrm{ppm}$ of boron $\times \mathrm{EW}$ compared with other interactions.

Table 2A showed the light extinction coefficient at 122 days after sowing that significantly $(\mathrm{P}<0.05)$ improved in EW compared with $\mathrm{SN}$ row direction. While, not significant differences among three cultivars, different level of boron, interactions between boron $\times$ cultivars and interactions among all three factors in light extinction coefficient parameter. Interactions between different level of boron with row direction significantly $(\mathrm{P}<0.05)$ improved light extinction coefficient, the best records were observed $0 \mathrm{ppm}$ of boron $\times \mathrm{EW}$ and $1.5 \mathrm{ppm}$ of boron $\times \mathrm{EW}$ compared with other interactions. Also, there were significant $(\mathrm{P}<0.05)$ differences among treatments of interaction between cultivars and row direction, the best records was observed V2 $\times$ EW compared with the other interactions.

\subsection{Reproductive growth characters}

Table 2B showed that not significant differences were observed among treatments in Plant height, Flag leaf length, Flowering day, Physiological maturity and fertility between row directions, different level of boron, cultivars, interactions between boron levels with cultivars and boron levels with row directions, except plant height in cultivars and interactions between boron levels with cultivars, also flag leaf length and Fertility in row direction and interaction between boron levels with row directions. Also table 2B showed that significant $(\mathrm{P}<0.05)$ differences were observed for all parameters between cultivars $\times$ row directions and all three factors boron levels $\times$ cultivars $\times$ row directions, the best records for Fertility were observed between (V1, V2 and V3 $\times$ $\mathrm{EW}$ directions) and $(0 \mathrm{ppm}$ boron $\times \mathrm{V} 3 \times \mathrm{EW})$ compared with other interactions, respectively. The results by [4] pointed that the EW row direction of the wheat crops is the best compared to the NS row direction, this result does not exactly mean that it is a standard case in all researches assumed in this gaps. At the same time, some researchers have published that the EW row direction of crops is the best in suppressing weed growth in wheat and increasing the yield of crops [19]. Other researchers have stated that the NS of row direction is also better in suppressing weed growing with wheat and increasing the yield crops [20]. Both have the same view that both row directions 
work by increasing shading between the row directions, which affects present weeds in the field area and subsequently increase the yield of crops. Increased yield of crops and ingredient are a natural reflection of what has been observed in the growth of plants. Raising strong healthy plants during the overall vegetable growth phase leads to a significant increase in harvest and final crop yields.

Table 3 showed that not significant differences were observed among treatments in a number of spikes plant ${ }^{-1}$, Spike weight (g), Spike length $(\mathrm{cm})$, number of Kernels Spike ${ }^{-1}$, Grain yield ( $\mathrm{g}$ plant $^{-1}$ ) between different level of boron, cultivars and interactions between boron levels with cultivars. While, the number of spikes plant ${ }^{-1}$ and harvest index (\%) was increased in EW row direction compared to SN row direction. While, all other parameters except 1000 kernels weight were increased in SN row direction compared to EW row direction. In the current study, the data showed in table 3, indicates that SN direction significantly increased grain yield compare to EW direction. This positive enhancements in grain yield have also been reported by previous research [21]. Also, significant differences were observed in the number of spikes in interactions between of boron levels $\times$ row direction, cultivars $\times$ row directions and all three factors, the best records were observed $(0 \mathrm{ppm}$ of boron $\times \mathrm{EW}),(\mathrm{V} 3 \times \mathrm{EW}$ and $\mathrm{V} 1 \times \mathrm{SN})$ and $(0 \mathrm{ppm}$ boron $\times \mathrm{V} 3 \times \mathrm{EW})$ compared to other interactions, respectively. The row direction can supply a concept to produce a good condition of light-saturated for a crop that cover for the aims of effective harvesting of solar power for the production of agriculture. The research was supported with the previous study at the Miniba Agricultural Center [22], which showed that seeding in the EW row direction increased the crop yield compared to the $\mathrm{SN}$ row direction during the experimental period.

Table 3 also shows not significant differences were observed among treatments in 1000 kernels weight in boron level and interaction between boron $\times$ row direction, Biological yield $\left(\mathrm{g} \mathrm{Plant}^{-1}\right)$ in boron level and Harvest index in boron level and different cultivars. Spike weight (g), Number of Kernels Spike ${ }^{-1}$, Grain yield $\left(\mathrm{g}_{\text {plant }}{ }^{-1}\right.$ ) and Biological yield of $\mathrm{V} 1 \times \mathrm{SN}$ row direction was significantly $(\mathrm{P}<0.05)$ increased compared to other interactions. While, 1000 kernels weight and Harvest index of V2 $\times$ EW were significantly $(\mathrm{P}<0.05)$ increased compared to other interactions. Also the interaction among three factors, Spike weight (g), Number of Kernels Spike ${ }^{-1}$, Grain yield $\left(\mathrm{g}\right.$ plant ${ }^{-1}$ ) and Biological yield of $1.5 \mathrm{ppm}$ boron $\times \mathrm{V} 1 \times \mathrm{SN}$ row direction was significantly $(\mathrm{P}<0.05)$ increased compared to other interactions.

The influence of the row direction on the crops is different from the latitude and the seasonal slope of the earth relative to the sun. Near the equator, the NS row direction (unlike east-west) gives the higher level of crop productions so that the light absorbs most of the year. In the upper latitudes (up to $55^{\circ}$ ), the absorption is higher in the NS row direction crop yields in the summer and the EW crops for the remaining of the year. From $65^{\circ}$, the EW row direction gives the greatest amount of light absorption throughout the year (although the difference between the directions is minimal [23]. Australia's western wheat girdle (wide grain growing area) ranges from $28^{\circ} \mathrm{C}$ to $33^{\circ} \mathrm{C}$. The planting appear during the winter-spring season, suggesting that crops between EW should receive the higher amount of light absorption compared to the SN row direction [24]. The angle of the sun (for the horizon) can be as low as $35^{\circ}$ during the winter planting crop season, although it ranges from $39-61^{\circ}$ in the spring, when the plants reach to maturity [25]. The results showed that by [8] grain yield and quality of different cultivars of wheat averaged in all characteristics, were significantly $(\mathrm{P}<0.001)$ higher for planting crops in the EW row direction, compared to the NS row direction (793 and $656 \mathrm{~kg}$ ha; 1; LSD = 69.3). Therefore, the interaction between the row directions and crop cultivars of the crop elucidate that which difference was often due to the various yield of wheat. Wheat yield (mean in all experiments) was $24 \%$ higher in the EW direction, not NS row directions. 
The research by [23] conducted an experiment with 21 wheat cultivars in the Taray region of India to estimate the influence of administration of $\mathrm{B}$ on grain yield and other vegetable and reproductive characteristics. Most cultivars displayed a significant $(\mathrm{P}<0.05)$ response to B related to grain yield 30, the number of grains per spike and length of the spike. Cereal yield was increased mainly by increasing the number of grains per spikes. While, cultivars such as BAU 2076, HI 968, BR 350 and BW 121 displayed a very small response to B additive for most the experiments. Similar data were presented by [23], [26] and [27] that showed a significant increases in the number of grain per spike of wheat by the addition of boron. The results by [27] showed that the addition of a different level of boron significantly affected the plant height. The data of the highest plant $(80.02 \mathrm{~cm})$ were recorded when the plant field was treated with boron level $(1.0 \mathrm{~kg} \mathrm{~B}$ $\left.\mathrm{ha}^{-1}\right)$, and also there were no statistically differences with other levels of boron $\left(0.5 \mathrm{~kg} \mathrm{~B} \mathrm{ha}^{-1}\right)$ and $\left(1.5 \mathrm{~kg} \mathrm{~B} \mathrm{ha}^{-1}\right)$. While, the shortest plant height $(76.85 \mathrm{~cm})$ was recorded whit no addition of boron to the wheat. Also, the research showed that plant height of wheat was significantly increased by administration of $1 \mathrm{~kg}$ of boron $\mathrm{ha}^{-1}$ [28]. Also, the research by [13] found that the effect of application of different level of boron significantly increased the grain yield at season 2003. While, the study by [29] used different level of boron $(0,0.5,1,1.5,2$ and 2.5 ppm) in Sulaymaniyah area and the result showed that increased level of boron equal and more than $2 \mathrm{ppm}$ that deceased the dry weight of crops. 
Table 2A: Response of some wheat cultivars to plot orientation, boron levels and interactions on vegetable traits.

\begin{tabular}{|c|c|c|c|c|c|}
\hline Treatment & No. of Tillers Plant ${ }^{-1}$ & Leaf Area $\left(\mathrm{cm}^{2}\right)$ & LAI & Weight of Leaf (g) & $\mathbf{K}$ \\
\hline \multicolumn{6}{|l|}{ Direction $^{1}$} \\
\hline $\mathrm{SN}$ & $1.60 \mathrm{a}$ & $273.46 \mathrm{~b}$ & $3.21 \mathrm{~b}$ & $1.92 \mathrm{~b}$ & $1.14 \mathrm{a}$ \\
\hline EW & $1.64 \mathrm{a}$ & $315.95 \mathrm{a}$ & $3.71 \mathrm{a}$ & $2.13 \mathrm{a}$ & $0.78 \mathrm{~b}$ \\
\hline \multicolumn{6}{|l|}{ Boron Level } \\
\hline $0 \mathrm{ppm}$ & $1.59 \mathrm{a}$ & 299.53 a & $3.52 \mathrm{a}$ & $2.29 \mathrm{a}$ & $0.83 \mathrm{a}$ \\
\hline 1 ppm & $1.60 \mathrm{a}$ & $296.71 \mathrm{a}$ & 3.49 a & $2.32 \mathrm{a}$ & $1.02 \mathrm{a}$ \\
\hline $1.5 \mathrm{ppm}$ & $1.67 \mathrm{a}$ & $287.88 \mathrm{a}$ & $3.38 \mathrm{a}$ & $2.01 \mathrm{a}$ & $1.02 \mathrm{a}$ \\
\hline \multicolumn{6}{|l|}{ Cultivar $^{2}$} \\
\hline V1 & $1.67 \mathrm{a}$ & $279.97 \mathrm{a}$ & $3.29 \mathrm{a}$ & $2.22 \mathrm{a}$ & $1.00 \mathrm{a}$ \\
\hline $\mathrm{V} 2$ & $1.68 \mathrm{a}$ & $309.85 \mathrm{a}$ & $3.64 \mathrm{a}$ & $2.28 \mathrm{a}$ & $0.91 \mathrm{a}$ \\
\hline V3 & $1.51 \mathrm{a}$ & $294.30 \mathrm{a}$ & $3.46 \mathrm{a}$ & $2.13 \mathrm{a}$ & $0.96 \mathrm{a}$ \\
\hline \multicolumn{6}{|l|}{ Interaction } \\
\hline \multicolumn{6}{|l|}{ Boron Level $\times$ Cultivar } \\
\hline $0 \mathrm{ppm} \times \mathrm{V} 1$ & $1.75 \mathrm{ab}$ & 296.97 a & $3.49 \mathrm{a}$ & $2.46 \mathrm{a}$ & $0.96 \mathrm{a}$ \\
\hline $0 \mathrm{ppm} \times \mathrm{V} 2$ & $1.59 \mathrm{ab}$ & $311.60 \mathrm{a}$ & $3.66 \mathrm{a}$ & $2.42 \mathrm{a}$ & $0.67 \mathrm{a}$ \\
\hline $0 \mathrm{ppm} \times \mathrm{V} 3$ & $1.41 \mathrm{~b}$ & $290.01 \mathrm{a}$ & $3.41 \mathrm{a}$ & $2.00 \mathrm{a}$ & $0.87 \mathrm{a}$ \\
\hline $1 \mathrm{ppm} \times \mathrm{V} 1$ & $1.45 \mathrm{ab}$ & $259.54 \mathrm{a}$ & $3.05 \mathrm{a}$ & $2.23 \mathrm{a}$ & $0.99 \mathrm{a}$ \\
\hline $1 \mathrm{ppm} \times \mathrm{V} 2$ & $1.75 \mathrm{ab}$ & 296.11 a & $3.48 \mathrm{a}$ & $2.23 \mathrm{a}$ & $1.15 \mathrm{a}$ \\
\hline $1 \mathrm{ppm} \times \mathrm{V} 3$ & $1.61 \mathrm{ab}$ & $334.49 \mathrm{a}$ & $3.93 \mathrm{a}$ & $2.50 \mathrm{a}$ & $0.93 \mathrm{a}$ \\
\hline $1.5 \mathrm{ppm} \times \mathrm{V} 1$ & $1.80 \mathrm{a}$ & $283.38 \mathrm{a}$ & $3.33 \mathrm{a}$ & $1.96 \mathrm{a}$ & $1.06 \mathrm{a}$ \\
\hline $1.5 \mathrm{ppm} \times \mathrm{V} 2$ & $1.69 \mathrm{ab}$ & $321.84 \mathrm{a}$ & $3.78 \mathrm{a}$ & $2.18 \mathrm{a}$ & $0.91 \mathrm{a}$ \\
\hline $1.5 \mathrm{ppm} \times \mathrm{V} 3$ & $1.52 \mathrm{ab}$ & $258.40 \mathrm{a}$ & $3.04 \mathrm{a}$ & $1.89 \mathrm{a}$ & $1.08 \mathrm{a}$ \\
\hline \multicolumn{6}{|l|}{ Boron Level $\times$ Direction } \\
\hline $0 \mathrm{ppm} \times \mathrm{SN}$ & $1.56 \mathrm{~ns}$ & $282.91 \mathrm{ab}$ & $3.32 \mathrm{ab}$ & $2.09 \mathrm{ab}$ & $0.93 \mathrm{ab}$ \\
\hline $1 \mathrm{ppm} \times \mathrm{SN}$ & $1.52 \mathrm{~ns}$ & $255.41 \mathrm{~b}$ & $3.00 \mathrm{~b}$ & $1.92 \mathrm{ab}$ & $1.20 \mathrm{ab}$ \\
\hline $1.5 \mathrm{ppm} \times \mathrm{SN}$ & $1.73 \mathrm{~ns}$ & $282.05 \mathrm{ab}$ & $3.31 \mathrm{ab}$ & $1.74 \mathrm{c}$ & $1.27 \mathrm{a}$ \\
\hline $0 \mathrm{ppm} \times \mathrm{EW}$ & $1.62 \mathrm{~ns}$ & $316.14 \mathrm{ab}$ & $3.71 \mathrm{ab}$ & $2.49 \mathrm{bc}$ & $0.74 \mathrm{~b}$ \\
\hline $1 \mathrm{ppm} \times \mathrm{EW}$ & $1.68 \mathrm{~ns}$ & 339.02 a & $3.97 \mathrm{a}$ & $2.72 \mathrm{a}$ & $0.85 \mathrm{ab}$ \\
\hline $1.5 \mathrm{ppm} \times \mathrm{EW}$ & $1.61 \mathrm{~ns}$ & $293.70 \mathrm{ab}$ & $3.45 \mathrm{ab}$ & $2.28 \mathrm{abc}$ & $0.76 \mathrm{~b}$ \\
\hline
\end{tabular}

Kurdistan Journal of Applied Research | Volume 4 - Issue 2 - December 2019 | 7 
Table 2A: Continued.

\begin{tabular}{|c|c|c|c|c|c|}
\hline Treatment & No. of Tillers Plant ${ }^{-1}$ & Leaf Area $\left(\mathrm{cm}^{2}\right)$ & LAI & Weight of Leaf & $\mathbf{K}$ \\
\hline \multicolumn{6}{|l|}{ Cultivar $\times$ Direction } \\
\hline $\mathrm{V} 1 \times \mathrm{SN}$ & $1.68 \mathrm{ab}$ & $257.47 \mathrm{~b}$ & $3.02 \mathrm{~b}$ & $1.79 \mathrm{~b}$ & $1.18 \mathrm{a}$ \\
\hline $\mathrm{V} 2 \times \mathrm{SN}$ & $1.73 \mathrm{a}$ & $274.69 \mathrm{ab}$ & $3.23 \mathrm{ab}$ & $1.92 \mathrm{~b}$ & $1.14 \mathrm{ab}$ \\
\hline $\mathrm{V} 3 \times \mathrm{SN}$ & $1.40 \mathrm{~b}$ & $288.21 \mathrm{ab}$ & $3.39 \mathrm{ab}$ & $2.05 \mathrm{ab}$ & $1.08 \mathrm{ab}$ \\
\hline $\mathrm{V} 1 \times \mathrm{EW}$ & $1.65 \mathrm{ab}$ & $302.46 \mathrm{ab}$ & $3.55 \mathrm{ab}$ & $2.65 \mathrm{a}$ & $0.82 \mathrm{ab}$ \\
\hline $\mathrm{V} 2 \times \mathrm{EW}$ & $1.63 \mathrm{ab}$ & $345.01 \mathrm{a}$ & $4.05 \mathrm{a}$ & $2.63 \mathrm{a}$ & $0.69 \mathrm{~b}$ \\
\hline $\mathrm{V} 3 \times \mathrm{EW}$ & $1.63 \mathrm{ab}$ & $300.39 \mathrm{ab}$ & $3.53 \mathrm{ab}$ & $2.21 \mathrm{ab}$ & $0.84 \mathrm{ab}$ \\
\hline \multicolumn{6}{|c|}{ Boron Level $\times$ Cultivar $\times$ Direction } \\
\hline $0 \mathrm{ppm} \times \mathrm{V} 1 \times \mathrm{SN}$ & $1.74 \mathrm{ab}$ & $289.24 \mathrm{ab}$ & $3.40 \mathrm{ab}$ & $2.21 \mathrm{abc}$ & 1.08 \\
\hline $0 \mathrm{ppm} \times \mathrm{V} 1 \times \mathrm{EW}$ & $1.77 \mathrm{a}$ & $304.71 \mathrm{ab}$ & $3.58 \mathrm{ab}$ & 2.71 bc & 0.84 \\
\hline $0 \mathrm{ppm} \times \mathrm{V} 2 \times \mathrm{SN}$ & $1.71 \mathrm{ab}$ & $280.66 \mathrm{ab}$ & $3.30 \mathrm{ab}$ & $2.21 \mathrm{abc}$ & 0.71 \\
\hline $0 \mathrm{ppm} \times \mathrm{V} 2 \times \mathrm{EW}$ & $1.48 \mathrm{ab}$ & $342.54 \mathrm{a}$ & $4.03 \mathrm{a}$ & $2.62 \mathrm{abc}$ & 0.63 \\
\hline $0 \mathrm{ppm} \times \mathrm{V} 3 \times \mathrm{SN}$ & $1.23 \mathrm{~b}$ & $278.83 \mathrm{ab}$ & $3.28 \mathrm{ab}$ & $1.86 \mathrm{abc}$ & 0.99 \\
\hline $0 \mathrm{ppm} \times \mathrm{V} 3 \times \mathrm{EW}$ & $1.60 \mathrm{ab}$ & $301.18 \mathrm{ab}$ & $3.54 \mathrm{ab}$ & $2.14 \mathrm{abc}$ & 0.75 \\
\hline $1 \mathrm{ppm} \times \mathrm{V} 1 \times \mathrm{SN}$ & $1.41 \mathrm{ab}$ & $196.99 \mathrm{~b}$ & $2.31 \mathrm{~b}$ & $1.52 \mathrm{c}$ & 1.33 \\
\hline $1 \mathrm{ppm} \times \mathrm{V} 1 \times \mathrm{EW}$ & $1.49 \mathrm{ab}$ & $322.09 \mathrm{ab}$ & $3.79 \mathrm{ab}$ & $2.95 \mathrm{a}$ & 0.65 \\
\hline $1 \mathrm{ppm} \times \mathrm{V} 2 \times \mathrm{SN}$ & $1.66 \mathrm{ab}$ & $265.60 \mathrm{ab}$ & $3.12 \mathrm{ab}$ & $1.85 \mathrm{abc}$ & 1.40 \\
\hline $1 \mathrm{ppm} \times \mathrm{V} 2 \times \mathrm{EW}$ & $1.85 \mathrm{a}$ & $326.62 \mathrm{ab}$ & $3.84 \mathrm{ab}$ & $2.62 \mathrm{abc}$ & 0.91 \\
\hline $1 \mathrm{ppm} \times \mathrm{V} 3 \times \mathrm{SN}$ & $1.50 \mathrm{ab}$ & $30362 \mathrm{ab}$ & $3.57 \mathrm{ab}$ & 2.39 abc & 0.88 \\
\hline $1 \mathrm{ppm} \times \mathrm{V} 3 \times \mathrm{EW}$ & $1.72 \mathrm{ab}$ & $365.36 \mathrm{a}$ & $4.30 \mathrm{a}$ & $2.60 \mathrm{abc}$ & 0.98 \\
\hline $1.5 \mathrm{ppm} \times \mathrm{V} 1 \times \mathrm{SN}$ & $1.90 \mathrm{a}$ & $286.17 \mathrm{ab}$ & $3.36 \mathrm{ab}$ & $1.64 \mathrm{bc}$ & 1.15 \\
\hline $1.5 \mathrm{ppm} \times \mathrm{V} 1 \times \mathrm{EW}$ & $1.69 \mathrm{ab}$ & $280.60 \mathrm{ab}$ & $3.30 \mathrm{ab}$ & $2.28 \mathrm{abc}$ & 0.97 \\
\hline $1.5 \mathrm{ppm} \times \mathrm{V} 2 \times \mathrm{SN}$ & $1.82 \mathrm{ab}$ & $277.81 \mathrm{ab}$ & $3.26 \mathrm{ab}$ & $1.71 \mathrm{bc}$ & 1.31 \\
\hline $1.5 \mathrm{ppm} \times \mathrm{V} 2 \times \mathrm{EW}$ & $1.57 \mathrm{ab}$ & $365.88 \mathrm{a}$ & $4.30 \mathrm{a}$ & $2.65 \mathrm{abc}$ & 0.52 \\
\hline $1.5 \mathrm{ppm} \times \mathrm{V} 3 \times \mathrm{SN}$ & $1.47 \mathrm{ab}$ & $282.18 \mathrm{ab}$ & $3.32 \mathrm{ab}$ & $1.88 \mathrm{abc}$ & 1.36 \\
\hline $1.5 \mathrm{ppm} \times \mathrm{V} 3 \times \mathrm{EW}$ & $1.58 \mathrm{ab}$ & $234.62 \mathrm{ab}$ & $2.79 \mathrm{ab}$ & 1.90 abc & 0.80 \\
\hline
\end{tabular}

Means within each column had the different subscript were differ significantly $(\mathrm{P}<0.05) . \mathrm{K}=$ Light extinction coefficient.

${ }^{1}$ SN: South-North and EW: East-West; ${ }^{2}$ V1: FLORKWA, V2: BAJ and V3: FRANKOLIN. 
Table 2B: Response of some wheat cultivars to plot orientation, boron levels and interactions on vegetable traits.

\begin{tabular}{|c|c|c|c|c|c|}
\hline Treatment & Plant Height (cm) & $\begin{array}{c}\text { Flag Leaf Length } \\
\text { (cm) }\end{array}$ & Flowering Day (Day) & $\begin{array}{l}\text { Physiological Maturity } \\
\text { (Day) }\end{array}$ & Fertility \% \\
\hline \multicolumn{6}{|l|}{ Direction } \\
\hline $\mathrm{SN}$ & $84.05 \mathrm{a}$ & $21.22 \mathrm{~b}$ & $131.77 \mathrm{a}$ & $178.92 \mathrm{a}$ & $65.34 \mathrm{~b}$ \\
\hline EW & $84.12 \mathrm{a}$ & $23.20 \mathrm{a}$ & 132.33 a & 179.66 a & $85.68 \mathrm{a}$ \\
\hline \multicolumn{6}{|l|}{ Boron Level } \\
\hline $0 \mathrm{ppm}$ & $84.40 \mathrm{a}$ & $22.28 \mathrm{a}$ & $130.66 \mathrm{a}$ & 179.88 a & $77.43 \mathrm{a}$ \\
\hline $1 \mathrm{ppm}$ & $83.12 \mathrm{a}$ & $22.48 \mathrm{a}$ & $131.22 \mathrm{a}$ & $178.44 \mathrm{a}$ & $74.48 \mathrm{a}$ \\
\hline $1.5 \mathrm{ppm}$ & $84.74 \mathrm{a}$ & $21.88 \mathrm{a}$ & 132.33 a & 179.55 a & $74.62 \mathrm{a}$ \\
\hline \multicolumn{6}{|l|}{ Cultivar } \\
\hline V1 & $79.25 \mathrm{~b}$ & $22.65 \mathrm{a}$ & 130.66 a & 177.88 a & 72.65 a \\
\hline $\mathrm{V} 2$ & 90.65 a & 20.96 a & 132.33 a & 179.33 a & $75.75 \mathrm{a}$ \\
\hline V3 & $82.36 \mathrm{~b}$ & $23.03 \mathrm{a}$ & 133.16 a & 180.66 a & $78.14 \mathrm{a}$ \\
\hline \multicolumn{6}{|l|}{ Interaction } \\
\hline \multicolumn{6}{|l|}{ Boron Level $\times$ Cultivar } \\
\hline $0 \mathrm{ppm} \times \mathrm{V} 1$ & $79.95 \mathrm{~b}$ & $22.62 \mathrm{a}$ & 132.33 a & 179.66 a & $72.69 \mathrm{a}$ \\
\hline $0 \mathrm{ppm} \times \mathrm{V} 2$ & $90.05 \mathrm{a}$ & $21.50 \mathrm{a}$ & 132.33 a & 179.33 a & $75.46 \mathrm{a}$ \\
\hline $0 \mathrm{ppm} \times \mathrm{V} 3$ & $83.20 \mathrm{~b}$ & $22.71 \mathrm{a}$ & $133.16 \mathrm{a}$ & $180.33 \mathrm{a}$ & $84.13 \mathrm{a}$ \\
\hline $1 \mathrm{ppm} \times \mathrm{V} 1$ & $78.40 \mathrm{~b}$ & $22.04 \mathrm{a}$ & 129.83 a & $177.00 \mathrm{a}$ & $73.97 \mathrm{a}$ \\
\hline $1 \mathrm{ppm} \times \mathrm{V} 2$ & $90.93 \mathrm{a}$ & $21.06 \mathrm{a}$ & $130.66 \mathrm{a}$ & $177.66 \mathrm{a}$ & $72.72 \mathrm{a}$ \\
\hline $1 \mathrm{ppm} \times \mathrm{V} 3$ & $80.03 \mathrm{~b}$ & $24.35 \mathrm{a}$ & 133.16 a & 180.66 a & $76.76 \mathrm{a}$ \\
\hline $1.5 \mathrm{ppm} \times \mathrm{V} 1$ & $79.41 \mathrm{~b}$ & $23.29 \mathrm{a}$ & 129.83 a & $177.00 \mathrm{a}$ & $71.29 \mathrm{a}$ \\
\hline $1.5 \mathrm{ppm} \times \mathrm{V} 2$ & $90.96 \mathrm{a}$ & 20.32 a & $134.00 \mathrm{a}$ & $181.00 \mathrm{a}$ & $79.06 \mathrm{a}$ \\
\hline $1.5 \mathrm{ppm} \times \mathrm{V} 3$ & $83.85 \mathrm{~b}$ & $22.03 \mathrm{a}$ & $133.16 \mathrm{a}$ & $180.66 \mathrm{a}$ & 73.52 a \\
\hline \multicolumn{6}{|l|}{ Boron Level $\times$ Direction } \\
\hline $0 \mathrm{ppm} \times \mathrm{SN}$ & $83.74 \mathrm{a}$ & $20.89 \mathrm{ab}$ & $131.77 \mathrm{a}$ & $179.00 \mathrm{a}$ & $64.68 \mathrm{~b}$ \\
\hline $1 \mathrm{ppm} \times \mathrm{SN}$ & $83.34 \mathrm{a}$ & $22.45 \mathrm{ab}$ & $131.22 \mathrm{a}$ & 178.33 a & $66.49 \mathrm{~b}$ \\
\hline $1.5 \mathrm{ppm} \times \mathrm{SN}$ & $85.07 \mathrm{a}$ & $20.33 \mathrm{~b}$ & 132.33 a & 179.44 a & $64.85 \mathrm{~b}$ \\
\hline $0 \mathrm{ppm} \times \mathrm{EW}$ & 85.05 a & 23.67 a & $133.44 \mathrm{a}$ & $180.77 \mathrm{a}$ & $90.18 \mathrm{a}$ \\
\hline $1 \mathrm{ppm} \times \mathrm{EW}$ & $82.90 \mathrm{a}$ & $22.51 \mathrm{ab}$ & $131.22 \mathrm{a}$ & $178.55 \mathrm{a}$ & $82.48 \mathrm{a}$ \\
\hline $1.5 \mathrm{ppm} \times \mathrm{EW}$ & $84.41 \mathrm{a}$ & $23.45 \mathrm{ab}$ & $132.33 \mathrm{a}$ & $179.66 \mathrm{a}$ & $84.39 \mathrm{a}$ \\
\hline
\end{tabular}

Kurdistan Journal of Applied Research | Volume 4 - Issue 2 - December 2019 | 9 
Table 2B: Continued

\begin{tabular}{|c|c|c|c|c|c|}
\hline Treatment & Plant Height (cm) & $\begin{array}{c}\text { Flag Leaf Length } \\
\text { (cm) }\end{array}$ & Flowering Day (Day) & $\begin{array}{l}\text { Physiological Maturity } \\
\text { (Day) }\end{array}$ & Fertility \% \\
\hline \multicolumn{6}{|l|}{ Cultivar $\times$ Direction } \\
\hline $\mathrm{V} 1 \times \mathrm{SN}$ & $71.47 \mathrm{~b}$ & $19.23 \mathrm{c}$ & $136.22 \mathrm{ab}$ & $183.66 \mathrm{a}$ & $64.08 \mathrm{~b}$ \\
\hline $\mathrm{V} 2 \times \mathrm{SN}$ & 90.66 a & 19.63 c & 131.77 c & $178.77 \mathrm{~b}$ & $64.46 \mathrm{~b}$ \\
\hline $\mathrm{V} 3 \times \mathrm{SN}$ & $90.02 \mathrm{a}$ & $24.80 \mathrm{ab}$ & $127.33 \mathrm{~d}$ & $174.33 \mathrm{c}$ & $67.48 \mathrm{~b}$ \\
\hline $\mathrm{V} 1 \times \mathrm{EW}$ & $87.03 \mathrm{a}$ & $26.06 \mathrm{a}$ & $125.11 \mathrm{~d}$ & $172.11 \mathrm{c}$ & $81.22 \mathrm{a}$ \\
\hline $\mathrm{V} 2 \times \mathrm{EW}$ & $90.63 \mathrm{a}$ & 22.29 bc & $132.88 \mathrm{bc}$ & $179.88 \mathrm{~b}$ & $87.03 \mathrm{a}$ \\
\hline $\mathrm{V} 3 \times \mathrm{EW}$ & $74.70 \mathrm{~b}$ & $21.26 \mathrm{c}$ & $139.00 \mathrm{a}$ & $187.00 \mathrm{a}$ & $88.80 \mathrm{a}$ \\
\hline \multicolumn{6}{|c|}{ Boron Level $\times$ Cultivar $\times$ Direction } \\
\hline $0 \mathrm{ppm} \times \mathrm{V} 1 \times \mathrm{SN}$ & $69.86 \mathrm{c}$ & 19.05 ef & $137.33 \mathrm{ab}$ & $185.00 \mathrm{ab}$ & 66.52 bcd \\
\hline $0 \mathrm{ppm} \times \mathrm{V} 1 \times \mathrm{EW}$ & 90.03 a & 26.20 abc & $127.33 \mathrm{~cd}$ & $174.33 \mathrm{~cd}$ & 78.87 abcd \\
\hline $0 \mathrm{ppm} \times \mathrm{V} 2 \times \mathrm{SN}$ & 91.33 & 19.76 def & 130.66 bcd & $177.66 \mathrm{bcd}$ & $59.27 \mathrm{~d}$ \\
\hline $0 \mathrm{ppm} \times \mathrm{V} 2 \times \mathrm{EW}$ & $88.60 \mathrm{a}$ & 23.25 abcdef & $134.00 \mathrm{abc}$ & $181.00 \mathrm{abc}$ & $91.66 \mathrm{ab}$ \\
\hline $0 \mathrm{ppm} \times \mathrm{V} 3 \times \mathrm{SN}$ & $89.86 \mathrm{a}$ & 23.86 abcde & $127.33 \mathrm{~cd}$ & $174.33 \mathrm{~cd}$ & 68.26 bcd \\
\hline $0 \mathrm{ppm} \times \mathrm{V} 3 \times \mathrm{EW}$ & 76.53 bc & 21.56 bcdef & $139.00 \mathrm{a}$ & $187.00 \mathrm{a}$ & $100 \mathrm{a}$ \\
\hline $1 \mathrm{ppm} \times \mathrm{V} 1 \times \mathrm{SN}$ & $72.46 \mathrm{c}$ & 18.45 ef & $135.66 \mathrm{ab}$ & $183.00 \mathrm{ab}$ & $63.85 \mathrm{~cd}$ \\
\hline $1 \mathrm{ppm} \times \mathrm{V} 1 \times \mathrm{EW}$ & $84.33 \mathrm{ab}$ & 25.63 abcd & $124.00 \mathrm{~d}$ & $171.00 \mathrm{~d}$ & 84.10 abcd \\
\hline $1 \mathrm{ppm} \times \mathrm{V} 2 \times \mathrm{SN}$ & $91.50 \mathrm{a}$ & 21.43 bcdef & 130.66 bcd & 177.66 bcd & $63.19 \mathrm{~cd}$ \\
\hline $1 \mathrm{ppm} \times \mathrm{V} 2 \times \mathrm{EW}$ & $91.33 \mathrm{a}$ & 20.69 bcdef & 130.66 bcd & 177.66 bcd & 82.25 abcd \\
\hline $1 \mathrm{ppm} \times \mathrm{V} 3 \times \mathrm{SN}$ & $87.03 \mathrm{a}$ & $27.48 \mathrm{a}$ & $127.33 \mathrm{~cd}$ & $174.33 \mathrm{~cd}$ & 72.42 bcd \\
\hline $1 \mathrm{ppm} \times \mathrm{V} 3 \times \mathrm{EW}$ & $73.03 \mathrm{c}$ & 21.23 bcdef & $139.00 \mathrm{a}$ & $187.00 \mathrm{a}$ & 81.11 abcd \\
\hline $1.5 \mathrm{ppm} \times \mathrm{V} 1 \times \mathrm{SN}$ & $72.10 \mathrm{c}$ & 20.21 cdef & $135.66 \mathrm{ab}$ & $183.00 \mathrm{ab}$ & $61.86 \mathrm{~cd}$ \\
\hline $1.5 \mathrm{ppm} \times \mathrm{V} 1 \times \mathrm{EW}$ & $86.73 \mathrm{a}$ & $26.36 \mathrm{ab}$ & $124.00 \mathrm{~d}$ & $171.00 \mathrm{~d}$ & 80.71 abcd \\
\hline $1.5 \mathrm{ppm} \times \mathrm{V} 2 \times \mathrm{SN}$ & $89.96 \mathrm{a}$ & $17.71 \mathrm{f}$ & $134.00 \mathrm{abc}$ & $181.00 \mathrm{abc}$ & $70.93 \mathrm{bcd}$ \\
\hline $1.5 \mathrm{ppm} \times \mathrm{V} 2 \times \mathrm{EW}$ & $91.66 \mathrm{a}$ & 22.93 abcdef & $134.00 \mathrm{abc}$ & $181.00 \mathrm{abc}$ & $87.19 \mathrm{abc}$ \\
\hline $1.5 \mathrm{ppm} \times \mathrm{V} 3 \times \mathrm{SN}$ & $93.16 \mathrm{a}$ & 23.06 abcdef & $127.33 \mathrm{~cd}$ & $174.33 \mathrm{~cd}$ & $61.76 \mathrm{~cd}$ \\
\hline $1.5 \mathrm{ppm} \times \mathrm{V} 3 \times \mathrm{EW}$ & $74.53 \mathrm{c}$ & 21.00 bcdef & 139.00 a & $187.00 \mathrm{a}$ & 85.29 abcd \\
\hline
\end{tabular}

Means within each column had the different subscript were differ significantly $(\mathrm{P}<0.05)$. GDD= Growing Degree Day

${ }^{1}$ SN: South-North and EW: East-West; ${ }^{2}$ V1: FLORKWA, V2: BAJ and V3: FRANKOLIN. 
Table 3: Response of some wheat cultivars to plot orientation, boron levels and interactions on reproductive traits in field experiment.

\begin{tabular}{|c|c|c|c|c|c|c|c|c|}
\hline Treatment & $\begin{array}{l}\text { No. of } \\
\text { Spikes } \\
\text { Plant }^{-1}\end{array}$ & $\begin{array}{c}\text { Spikes } \\
\text { weight (g } \\
\text { Plant }^{-1} \text { ) }\end{array}$ & $\begin{array}{c}\text { Spikes } \\
\text { length }(\mathbf{c m})\end{array}$ & $\begin{array}{c}\text { No. of } \\
\text { kernels } \\
\text { Spikes }^{-1}\end{array}$ & $\begin{array}{l}1000 \text { kernels } \\
\text { weight (g) }\end{array}$ & $\begin{array}{c}\text { Grain yield } \\
\text { (g plant }^{-1} \text { ) }\end{array}$ & $\begin{array}{c}\text { Biological } \\
\text { yield (g plant } \\
\text { 1) }\end{array}$ & $\begin{array}{l}\text { Harvest } \\
\text { index \% }\end{array}$ \\
\hline \multicolumn{9}{|l|}{ Direction } \\
\hline $\mathrm{SN}$ & $1.04 \mathrm{~b}$ & $2.90 \mathrm{a}$ & $8.67 \mathrm{a}$ & $41.45 \mathrm{a}$ & $50.46 \mathrm{a}$ & $1.90 \mathrm{a}$ & $5.03 \mathrm{a}$ & $39.00 \mathrm{~b}$ \\
\hline EW & $1.40 \mathrm{a}$ & $1.95 \mathrm{~b}$ & $6.91 \mathrm{~b}$ & $31.45 \mathrm{~b}$ & 49.38 a & $1.57 \mathrm{~b}$ & $3.40 \mathrm{~b}$ & $46.68 \mathrm{a}$ \\
\hline \multicolumn{9}{|l|}{ Boron Level } \\
\hline $0 \mathrm{ppm}$ & $1.22 \mathrm{a}$ & $2.40 \mathrm{a}$ & $7.97 \mathrm{a}$ & $35.81 \mathrm{a}$ & 50.36 a & $1.72 \mathrm{a}$ & $4.25 \mathrm{a}$ & $41.97 \mathrm{a}$ \\
\hline $1 \mathrm{ppm}$ & $1.18 \mathrm{a}$ & $2.36 \mathrm{a}$ & $7.77 \mathrm{a}$ & $36.52 \mathrm{a}$ & $49.27 \mathrm{a}$ & $1.72 \mathrm{a}$ & $4.10 \mathrm{a}$ & $43.52 \mathrm{a}$ \\
\hline $1.5 \mathrm{ppm}$ & $1.25 \mathrm{a}$ & $2.53 \mathrm{a}$ & $7.65 \mathrm{a}$ & $37.02 \mathrm{a}$ & 50.13 a & $1.77 \mathrm{a}$ & $4.30 \mathrm{a}$ & $43.02 \mathrm{a}$ \\
\hline \multicolumn{9}{|l|}{ Cultivar } \\
\hline V1 & $1.21 \mathrm{a}$ & $2.57 \mathrm{a}$ & $7.83 \mathrm{a}$ & $39.23 \mathrm{a}$ & $47.02 \mathrm{~b}$ & $1.76 \mathrm{a}$ & $4.61 \mathrm{a}$ & $40.40 \mathrm{a}$ \\
\hline V2 & $1.25 \mathrm{a}$ & $2.48 \mathrm{a}$ & $8.10 \mathrm{a}$ & $35.95 \mathrm{a}$ & $53.55 \mathrm{a}$ & $1.81 \mathrm{a}$ & $4.26 \mathrm{ab}$ & $43.98 \mathrm{a}$ \\
\hline V3 & $1.20 \mathrm{a}$ & $2.23 \mathrm{a}$ & $7.46 \mathrm{a}$ & $34.16 \mathrm{a}$ & $49.19 \mathrm{~b}$ & $1.64 \mathrm{a}$ & $3.76 \mathrm{~b}$ & $44.13 \mathrm{a}$ \\
\hline \multicolumn{9}{|l|}{ Interaction } \\
\hline \multicolumn{9}{|l|}{ Boron Level $\times$ Cultivar } \\
\hline $0 \mathrm{ppm} \times \mathrm{V} 1$ & $1.27 \mathrm{a}$ & $2.60 \mathrm{a}$ & $7.98 \mathrm{a}$ & $39.55 \mathrm{a}$ & 47.66 bc & $1.77 \mathrm{a}$ & $4.68 \mathrm{ab}$ & $39.53 \mathrm{ab}$ \\
\hline $0 \mathrm{ppm} \times \mathrm{V} 2$ & $1.18 \mathrm{a}$ & $2.25 \mathrm{a}$ & $8.23 \mathrm{a}$ & $34.01 \mathrm{a}$ & 52.25 abc & $1.68 \mathrm{a}$ & $3.91 \mathrm{ab}$ & $43.78 \mathrm{ab}$ \\
\hline $0 \mathrm{ppm} \times \mathrm{V} 3$ & $1.23 \mathrm{a}$ & $2.35 \mathrm{a}$ & $7.70 \mathrm{a}$ & $33.88 \mathrm{a}$ & 51.16 abc & $1.70 \mathrm{a}$ & $4.15 \mathrm{ab}$ & $42.60 \mathrm{ab}$ \\
\hline $1 \mathrm{ppm} \times \mathrm{V} 1$ & $1.07 \mathrm{a}$ & $2.53 \mathrm{a}$ & $7.73 \mathrm{a}$ & $37.28 \mathrm{a}$ & $45.50 \mathrm{c}$ & $1.63 \mathrm{a}$ & $4.73 \mathrm{a}$ & $35.54 \mathrm{~b}$ \\
\hline $1 \mathrm{ppm} \times \mathrm{V} 2$ & $1.25 \mathrm{a}$ & $2.46 \mathrm{a}$ & $8.25 \mathrm{a}$ & $37.88 \mathrm{a}$ & $54.83 \mathrm{a}$ & $1.94 \mathrm{a}$ & $4.16 \mathrm{ab}$ & $48.23 \mathrm{a}$ \\
\hline $1 \mathrm{ppm} \times \mathrm{V} 3$ & $1.24 \mathrm{a}$ & $2.10 \mathrm{a}$ & $7.34 \mathrm{a}$ & $34.40 \mathrm{a}$ & $47.50 \mathrm{bc}$ & $1.60 \mathrm{a}$ & $3.40 \mathrm{~b}$ & $46.80 \mathrm{a}$ \\
\hline $1.5 \mathrm{ppm} \times \mathrm{V} 1$ & $1.28 \mathrm{a}$ & $2.58 \mathrm{a}$ & $7.78 \mathrm{a}$ & $40.88 \mathrm{a}$ & $47.91 \mathrm{abc}$ & $1.89 \mathrm{a}$ & $4.43 \mathrm{ab}$ & $46.12 \mathrm{a}$ \\
\hline $1.5 \mathrm{ppm} \times \mathrm{V} 2$ & $1.33 \mathrm{a}$ & $2.75 \mathrm{a}$ & $7.82 \mathrm{a}$ & $35.96 \mathrm{a}$ & $53.58 \mathrm{ab}$ & $1.81 \mathrm{a}$ & $4.71 \mathrm{ab}$ & $39.93 \mathrm{ab}$ \\
\hline $1.5 \mathrm{ppm} \times \mathrm{V} 3$ & $1.13 \mathrm{a}$ & $2.26 \mathrm{a}$ & $7.35 \mathrm{a}$ & $34.21 \mathrm{a}$ & $48.91 \mathrm{abc}$ & $1.62 \mathrm{a}$ & $3.75 \mathrm{ab}$ & $43.02 \mathrm{ab}$ \\
\hline \multicolumn{9}{|l|}{ Boron Level ×Direction } \\
\hline $0 \mathrm{ppm} \times \mathrm{SN}$ & $1.00 \mathrm{c}$ & $2.81 \mathrm{a}$ & $8.81 \mathrm{a}$ & $39.58 \mathrm{ab}$ & $50.22 \mathrm{a}$ & $1.81 \mathrm{ab}$ & $4.93 \mathrm{a}$ & $37.31 \mathrm{c}$ \\
\hline $1 \mathrm{ppm} \times \mathrm{SN}$ & $0.99 \mathrm{c}$ & $2.71 \mathrm{a}$ & $8.56 \mathrm{a}$ & $41.17 \mathrm{a}$ & $49.66 \mathrm{a}$ & $1.89 \mathrm{ab}$ & $4.80 \mathrm{a}$ & $41.33 \mathrm{abc}$ \\
\hline $1.5 \mathrm{ppm} \times \mathrm{SN}$ & $1.13 \mathrm{bc}$ & $3.20 \mathrm{a}$ & $8.65 \mathrm{a}$ & $43.58 \mathrm{a}$ & $51.50 \mathrm{a}$ & $2.02 \mathrm{a}$ & $5.35 \mathrm{a}$ & 38.35 bc \\
\hline $0 \mathrm{ppm} \times \mathrm{EW}$ & $1.45 \mathrm{a}$ & $1.98 \mathrm{~b}$ & $7.13 \mathrm{~b}$ & 32.04 bc & $50.50 \mathrm{a}$ & $1.62 \mathrm{ab}$ & $3.56 \mathrm{~b}$ & $46.63 \mathrm{a}$ \\
\hline $1 \mathrm{ppm} \times \mathrm{EW}$ & $1.38 \mathrm{ab}$ & $2.02 \mathrm{~b}$ & $6.97 \mathrm{~b}$ & $31.87 \mathrm{bc}$ & $48.88 \mathrm{a}$ & $1.56 \mathrm{~b}$ & $3.40 \mathrm{~b}$ & $45.71 \mathrm{ab}$ \\
\hline $1.5 \mathrm{ppm} \times \mathrm{EW}$ & $1.36 \mathrm{ab}$ & $1.86 \mathrm{~b}$ & $6.64 \mathrm{~b}$ & $30.45 \mathrm{c}$ & $48.77 \mathrm{a}$ & $1.53 \mathrm{~b}$ & $3.24 \mathrm{~b}$ & $47.69 \mathrm{a}$ \\
\hline
\end{tabular}

Kurdistan Journal of Applied Research | Volume 4 - Issue 2 - December 2019 | 11 
Table 3: Continued

\begin{tabular}{|c|c|c|c|c|c|c|c|c|}
\hline Treatment & $\begin{array}{l}\text { No. of } \\
\text { Spikes } \\
\text { Plant }^{-1}\end{array}$ & $\begin{array}{c}\text { Spikes } \\
\text { weight (g } \\
\text { Plant }^{-1} \text { ) }\end{array}$ & $\begin{array}{c}\text { Spikes } \\
\text { length }(\mathbf{c m})\end{array}$ & $\begin{array}{l}\text { No. of kernels } \\
\text { Spikes }^{-1}\end{array}$ & $\begin{array}{c}1000 \\
\text { kernels } \\
\text { weight (g) }\end{array}$ & $\begin{array}{l}\text { Grain yield } \\
\text { (g plant }^{-1} \text { ) }\end{array}$ & $\begin{array}{l}\text { Biological yield } \\
\quad\left(\text { g plant }^{-1}\right)\end{array}$ & $\begin{array}{l}\text { Harvest } \\
\text { index } \%\end{array}$ \\
\hline \multicolumn{9}{|c|}{ Cultivar $\times$ Direction } \\
\hline $\mathrm{V} 1 \times \mathrm{SN}$ & $1.08 \mathrm{bc}$ & $3.13 \mathrm{a}$ & $8.70 \mathrm{a}$ & $48.12 \mathrm{a}$ & $47.11 \mathrm{~b}$ & $1.97 \mathrm{a}$ & $5.82 \mathrm{a}$ & $33.98 \mathrm{c}$ \\
\hline $\mathrm{V} 2 \times \mathrm{SN}$ & $1.11 \mathrm{bc}$ & $2.84 \mathrm{a}$ & $8.60 \mathrm{a}$ & $38.76 \mathrm{~b}$ & $52.83 \mathrm{a}$ & $1.86 \mathrm{a}$ & $4.86 \mathrm{~b}$ & 38.94 bc \\
\hline $\mathrm{V} 3 \times \mathrm{SN}$ & $0.94 \mathrm{c}$ & $2.71 \mathrm{~b}$ & $8.72 \mathrm{a}$ & $37.46 \mathrm{~b}$ & $51.44 \mathrm{ab}$ & $1.88 \mathrm{a}$ & $4.40 \mathrm{bc}$ & $44.07 \mathrm{ab}$ \\
\hline $\mathrm{V} 1 \times \mathrm{EW}$ & $1.33 \mathrm{ab}$ & 1.97 c & $6.97 \mathrm{bc}$ & $30.35 \mathrm{~b}$ & $46.94 \mathrm{~b}$ & $1.55 \mathrm{ab}$ & $3.41 \mathrm{~d}$ & $46.82 \mathrm{ab}$ \\
\hline $\mathrm{V} 2 \times \mathrm{EW}$ & $1.38 \mathrm{a}$ & 2.13 bc & $7.59 \mathrm{ab}$ & $33.14 \mathrm{~b}$ & $54.27 \mathrm{a}$ & $1.75 \mathrm{ab}$ & $3.66 \mathrm{~cd}$ & $49.01 \mathrm{a}$ \\
\hline $\mathrm{V} 3 \times \mathrm{EW}$ & $1.46 \mathrm{a}$ & $1.76 \mathrm{c}$ & $6.20 \mathrm{c}$ & $30.87 \mathrm{~b}$ & $46.94 \mathrm{~b}$ & $1.40 \mathrm{~b}$ & $3.13 \mathrm{~d}$ & $44.20 \mathrm{ab}$ \\
\hline \multicolumn{9}{|c|}{$\begin{array}{l}\text { Boron Level } \times \text { Cultivar } \\
\times \text { Direction }\end{array}$} \\
\hline $0 \mathrm{ppm} \times \mathrm{V} 1 \times \mathrm{SN}$ & 1.16 abcd & $3.13 \mathrm{ab}$ & $8.80 \mathrm{ab}$ & $49.83 \mathrm{ab}$ & $46.00 \mathrm{~b}$ & $1.92 \mathrm{ab}$ & $5.63 \mathrm{ab}$ & 33.94 de \\
\hline $0 \mathrm{ppm} \times \mathrm{V} 1 \times \mathrm{EW}$ & $1.38 \mathrm{abc}$ & 2.06 bc & $7.16 \mathrm{abc}$ & $29.26 \mathrm{c}$ & $49.33 \mathrm{ab}$ & $1.62 \mathrm{ab}$ & $3.73 \mathrm{~cd}$ & 45.13 abcde \\
\hline $0 \mathrm{ppm} \times \mathrm{V} 2 \times \mathrm{SN}$ & $1.00 \mathrm{bcd}$ & $2.36 \mathrm{abc}$ & 8.40 abc & 33.16 bc & $51.66 \mathrm{ab}$ & $1.65 \mathrm{ab}$ & $4.10 \mathrm{bcd}$ & 40.15 bcde \\
\hline $0 \mathrm{ppm} \times \mathrm{V} 2 \times \mathrm{EW}$ & 1.36 abcd & $2.13 \mathrm{bc}$ & $8.06 \mathrm{abc}$ & $34.86 \mathrm{abc}$ & $52.83 \mathrm{ab}$ & $1.70 \mathrm{ab}$ & $3.73 \mathrm{~cd}$ & $47.41 \mathrm{abcd}$ \\
\hline $0 \mathrm{ppm} \times \mathrm{V} 3 \times \mathrm{SN}$ & $0.84 \mathrm{~d}$ & $2.93 \mathrm{abc}$ & $9.23 \mathrm{a}$ & $35.76 \mathrm{abc}$ & $53.00 \mathrm{ab}$ & $1.86 \mathrm{ab}$ & $5.06 \mathrm{abc}$ & 37.85 cde \\
\hline $0 \mathrm{ppm} \times \mathrm{V3} \times \mathrm{EW}$ & $1.60 \mathrm{a}$ & $1,76 \mathrm{c}$ & $6.16 \mathrm{c}$ & $32.00 \mathrm{c}$ & $49.33 \mathrm{ab}$ & $1.55 \mathrm{ab}$ & $3.23 \mathrm{~cd}$ & 47.34 abcd \\
\hline $1 \mathrm{ppm} \times \mathrm{V} 1 \times \mathrm{SN}$ & $0.88 \mathrm{~cd}$ & $2.93 \mathrm{abc}$ & $8.50 \mathrm{abc}$ & $41.90 \mathrm{abc}$ & $45.83 \mathrm{~b}$ & $1.81 \mathrm{ab}$ & $5.83 \mathrm{ab}$ & $31.55 \mathrm{e}$ \\
\hline $1 \mathrm{ppm} \times \mathrm{V} 1 \times \mathrm{EW}$ & 1.25 abcd & 2.13 bc & $6.96 \mathrm{abc}$ & $31.13 \mathrm{c}$ & $45.16 \mathrm{~b}$ & $1.45 \mathrm{ab}$ & $3.63 \mathrm{~cd}$ & 39.53 bcde \\
\hline $1 \mathrm{ppm} \times \mathrm{V} 2 \times \mathrm{SN}$ & $1.03 \mathrm{bcd}$ & $2.73 \mathrm{abc}$ & $8.75 \mathrm{ab}$ & $43.43 \mathrm{abc}$ & $53.16 \mathrm{ab}$ & $1.99 \mathrm{ab}$ & 4.76 abcd & 41.91 abcde \\
\hline $1 \mathrm{ppm} \times \mathrm{V} 2 \times \mathrm{EW}$ & $1.47 \mathrm{ab}$ & $2.20 \mathrm{abc}$ & 7.73 abc & 33.86 bc & $56.50 \mathrm{a}$ & $1.89 \mathrm{ab}$ & $3.56 \mathrm{~cd}$ & $54.56 \mathrm{ab}$ \\
\hline $1 \mathrm{ppm} \times \mathrm{V} 3 \times \mathrm{SN}$ & $1.07 \mathrm{bcd}$ & $2.46 \mathrm{abc}$ & $8.45 \mathrm{abc}$ & 38.18 abc & $50.00 \mathrm{ab}$ & $1.87 \mathrm{ab}$ & $3.80 \mathrm{~cd}$ & $50.55 \mathrm{abc}$ \\
\hline $1 \mathrm{ppm} \times \mathrm{V} 3 \times \mathrm{EW}$ & $1.41 \mathrm{abc}$ & $1.73 \mathrm{c}$ & $6.23 \mathrm{c}$ & $30.63 \mathrm{c}$ & $45.00 \mathrm{~b}$ & $1.33 \mathrm{~b}$ & $3.00 \mathrm{~d}$ & 43.06 abcde \\
\hline $1.5 \mathrm{ppm} \times \mathrm{V} 1 \times \mathrm{SN}$ & 1.20 abcd & $3.43 \mathrm{a}$ & $8.82 \mathrm{ab}$ & $51.10 \mathrm{a}$ & $49.50 \mathrm{ab}$ & $2.19 \mathrm{a}$ & $6.00 \mathrm{a}$ & 36.44 cde \\
\hline $1.5 \mathrm{ppm} \times \mathrm{V} 1 \times \mathrm{EW}$ & $1.37 \mathrm{abc}$ & $1.73 \mathrm{c}$ & $6.73 \mathrm{bc}$ & $30.66 \mathrm{c}$ & $46.33 \mathrm{ab}$ & $1.60 \mathrm{ab}$ & $2.86 \mathrm{~d}$ & $55.80 \mathrm{a}$ \\
\hline $1.5 \mathrm{ppm} \times \mathrm{V} 2 \times \mathrm{SN}$ & $1.30 \mathrm{abcd}$ & $3.43 \mathrm{a}$ & $8.66 \mathrm{ab}$ & 41.23 abc & $53.66 \mathrm{ab}$ & $1.96 \mathrm{ab}$ & $5.73 \mathrm{ab}$ & 34.78 de \\
\hline $1.5 \mathrm{ppm} \times \mathrm{V} 2 \times \mathrm{EW}$ & 1.36 abcd & 2.06 bc & $6.98 \mathrm{abc}$ & $3070 \mathrm{c}$ & $53.50 \mathrm{ab}$ & $1.67 \mathrm{ab}$ & $3.70 \mathrm{~cd}$ & 45.07 abcde \\
\hline $1.5 \mathrm{ppm} \times \mathrm{V} 3 \times \mathrm{SN}$ & $0.90 \mathrm{~cd}$ & $2.73 \mathrm{abc}$ & $8.48 \mathrm{abc}$ & $38.43 \mathrm{abc}$ & $51.33 \mathrm{ab}$ & $1.90 \mathrm{ab}$ & 4.33 abcd & 43.82 abcde \\
\hline $1.5 \mathrm{ppm} \times \mathrm{V} 3 \times \mathrm{EW}$ & 1.36 abcd & $1.80 \mathrm{c}$ & $6.22 \mathrm{c}$ & $30.00 \mathrm{c}$ & $46.50 \mathrm{ab}$ & $1.33 \mathrm{~b}$ & $3.16 \mathrm{~cd}$ & 42.21 abcde \\
\hline
\end{tabular}

Means within each column had the different subscript were differ significantly $(\mathrm{P}<0.05)$

${ }^{1}$ SN: South-North and EW: East-West; ${ }^{2}$ V1: FLORKWA, V2: BAJ and V3: FRANKOLIN. 


\section{CONCLUSION}

The present study confirms that response of some wheat cultivars to plot orientation (row direction) and boron levels; the results showed that Leaf area, LAI, weight of leaf, light extinction coefficient, flag leaf length, fertility, number of spike and Harvest index significantly increased in EW compared to SN row direction. While, the spike weight, spike length, number of kernels, grain yield and biological yield significantly increased in SN compare to EW row direction. There were not significant differences were observed among different level of boron alone and different cultivars in all vegetable and reproductive traits in this study except plant height and 1000 kernels weight of V2 increased compared to other cultivars. Interactions of EW direction with both cultivars and levels of boron factors were improved the vegetable characteristics compared to NS directions. Grain yield of interaction between $1.5 \mathrm{ppm} \times \mathrm{SN}$, all cultivars $\times \mathrm{SN}$ and $1.5 \mathrm{ppm}$ boron $\times \mathrm{V} 1 \times$ SN row direction were significantly $(\mathrm{P}<0.05)$ increased compared to other interactions. While the harvest index increased in interaction between 0 and $1.5 \mathrm{ppm} \times \mathrm{EW}, \mathrm{V} 2 \times \mathrm{EW}$ and 1.5 $\mathrm{ppm} \times \mathrm{V} 1 \times \mathrm{EW}$ compared to other interactions.

\section{REFERENCES}

[1] FAO. Food and Agriculture organization, “Food Outlook - Biannual Report on Global Food Markets”. P. 3., 2018.

[2] M. Hozayn, T. A. El-Shahawy and F. A. Sharara, "Implication of Crop Row Orientation and Row Spacing for Controlling Weeds and Increasing Yield in Wheat”. Australian Journal of Basic and Applied Sciences, 6(3): 422427, 2012.

[3] P .Catherine, D. Borger, A. Hashem and S. Pathan, “ Manipulating Crop Row Orientation on Suppress Weeds and Increase Crop Yield”. Weed Science, 58, 174-178, 2010.

[4] W.J. Grichar, B.A. Besler and K.D. Brewer, "Effect of row spacing and herbicide dose on weed control and grain sorghum yield”. Crop Prot., 23(3): 263-267, 2004.

[5] D.J. Connor, A. Centeno and M. Gomez-del-Campo, Yield determination in olive hedgerow orchards. II. Analysis of radiation and fruiting profiles. Crop Pasture Sci., 60: 443-452, 2009.

[6] B.S. Chauhan and D.E. Johnson. "Implications of narrow crop row spacing and delayed Echinochloa colona and Echinochloa crusgalli emergence for weed growth and crop yield loss in aerobic rice”. Field Crops Res., 117(3): 177-182, 2010.

[7] B.S. Chauhan and D.E. Johnson, “Row spacing and weed control timing affect yield of aerobic rice”. Field Crops Res., 121(2): 226-231, 2011.

[8] S. Drews, D. Neuhoff and U. Kopke, "Weed sup- pression ability of three winter wheat varieties at different row spacing under organic farming conditions”. Weed Research, 49, 526-533, 2009.

[9] U. C. Gupta, “Boron and its Role in Crop Production”. CRC Press, Boca Ration, FL, USA, 1993.

[10] P. Brown, N. Bellaloui, M.A. Wimmer, E.S. Bassil, J. Ruiz, H. Hu, H. Pfeffer, F. Dannel and V. Romheld, "Boron in plant biology. Plant Biol.;4:205-223, 2002.

[11] Blevins, D. G. and Lukaszewski K. M. “Boron in plant structure and function”. Annu. Rev. Plant Physiology and Plant Molecular Biology. 49: 481-500, 1998.

[12] I. Cakmak, H. Marschner and F. Bangerth, "Effect of zinc nutrition status on growth, protein metabolism and level of indole-3 acetic acid and other phytohormones in bean (Phaseolus vulgaris L.)”. Journal of Experimental Botany, 40: 405-412. ,1989.

[13] M. F. Al-Hassan, “Tillering pattern and capacity of five wheat cultivars Triticum aestivum L. as influenced by sowing rate and its relationship to grain yield and its components”. M.Sc. Thesis, College of Agriculture, Bagdad University, Field Cops Department. P121, 2007.

[14] D. B. Duncan, "Multiple range and Multiple F test” . Bometrics . 11:1-42, 1995

[15] R. Ahmad and M. Irshad, "Effect of boron application time on yield of wheat, rice and cotton crop in Pakistan”. Soil \& Environment. 30(1): 50-57, 2011.

[16] Amin, S. M. "Foliar application of different boron levels on some wheat cultivars as a response inducer to drought resistance”. Zanko Journal of Pure and Applied Sciences, 17(2): 53-61, 2005.

[17] D. Rajna, D. Washu, B. Shazia, K. Nawaz, M. Shabana, H. Ghulam and J. Qamaruddin. "Boron application using optimizing dose and time through foliar application for enhancing yield of wheat”. Science International (Lahore), 28(4): 4039-4042, 2016.

[18] Z. Tiago, S. Fábio, P. S. Edleusa, D. C. Deise and E. Gabriel, "Foliar application of calcium and boron improves the spike fertility and yield of wheat”. Bioscience Journal, 32(4): 873-880, 2016.

[19] C.P.D. Borger, A. Hasem and S. Pathan, "Manipulating crop row orientation to suppress weeds and increase crop yield”. Weed Sci., 58: 174-178, 2010. 
[20] D.J. Lyon, A.R. Martin and R.N. Klein, “Cultural practices to improve weed control in winter wheat”. Published by University of Nebraska-Lincoln Extension, Institute of Agriculture and Natural Resources. Online at: http://www.ianrpubs.unl.edu/epublic/live/g1389/build/g1389.pdf. Accessed Jan., 2011. Verified Sept., 2011, 2006.

[21] B. P. Pandey, B. B. Komal, R. B. Madan, Shrawan K. S., Resham B.T., Tanka P. K. "Effect of row spacing and direction of sowing on yield and yield attributing characters of wheat cultivated in Western Chitwan, Nepal", Agricultural Sciences , 4(7) 309-316, 2013.

[22] A. Cook, W. Shepperd and J. Hancock, "Row Direction and Stubble Cover”. EPFS Summary, p114-115, (2009).

[23] H.J.W. Mutsaers, "The effect of row orientation, date and latitude on light absorption by row crops". J. Agric. Sei. 95:381-386, 1980.

[24] Geoscience Australia. "Compute Sun and Moon Azimuth and Elevation". http://www.ga.gov.au/geodesy/astro/smpos.jsp. Accessed: September 17, 2009.

[25] A.B. Mandal, "Effect of Boron on Different Varieties of Bread Wheat (Triticum aestivum L.)”. Crop Res. 6: 330-334, 1993.

[26] S. Rahman, "Influence of different nutrients on grain formation in wheat”. Thesis M.Sc. (Ag).in Soil Sci. Bangladesh Argil. Univ. Mymensingh. pp. 33-34, 1989.

[27] D. R. Sarkar, "Effect of micronutrients on the growth and yield of wheat". M.Sc. Thesis, Soil Science, Sher-EBangla Agricultural University, Dhaka, 2014.

[28] Bina, (Bangladesh Institute of Nuclear Agriculture). "Effect of different levels of boron application on the growth and yield of wheat”. Ann. Rep. (1991-92). Bangladesh Inst. Nuclear Agric., Mymensingh. p. 159, 1993.

[29] Mohammad, D. A. "The Effect of boron on some soil and water characters in Sulaymaniyah area". M.Sc. Thesis, College of Agriculture, Salahaddin University, Erbil,1987. 